\title{
Comparative changes between pancreas and pancreatic juice digestive enzyme contents during nutritional rehabilitation following severe protein malnutrition in the rat
}

\author{
BY KHADIJA MOHAMED-BENKADA \\ Laboratoire de Physiologie Animale et de la Nutrition, Institut des Sciences de la Nature, \\ Université Es Sénia, Oran, Algérie \\ AND JACQUES BELLEVILLE AND JOSIANE PROST \\ Unité de Recherches de Nutrition Cellulaire et Métabolique, Faculté des Sciences Mirande, \\ Université de Bourgogne, BP 138, 21004 Dijon Cedex, France
}

(Received 29 May 1991 - Accepted 21 February 1992)

\begin{abstract}
The relationship between digestive enzyme activities in the pancreas and pancreatic juice was studied in post-weaning rats fed on a low-protein diet ( $30 \mathrm{~g}$ cereal protein/ $\mathrm{kg}$ ) for 1 month and a refeeding balanced diet ( $235 \mathrm{~g}$ mixed protein $/ \mathrm{kg}$ ) for the following 3 months. A control group was fed on the balanced diet for 4 months. At the end of malnutrition and at various times of refeeding, activities of amylase (EC 3.2.1.1), trypsin (EC 3.4.21.4), chymotrypsin (EC 3.4.21 1), lipase (EC 3.1.1.3), phospholipase A2 $(E C 3.1 .1 .4)$ and cholesterolesterase $(E C 3.1 .1 .13)$ in pancreas and pancreatic juice were measured. Recovery of body and pancreas weights was obtained after 3 months of refeeding. Pancreas offered a higher resistance to the low-protein diet; a quicker recovery than that of the whole organism was observed during refeeding. Protein and RNA contents of pancreatic cells were depressed by protein depletion. At the end of refeeding, pancreatic and cell RNA contents were still depressed. In pancreas and pancreatic juice, protein depletion produced a decrease in enzyme activities, with the exception of phospholipase A2 and cholesterolesterase. During refeeding, activities were increased to various levels in pancreatic juice and pancreas. In pancreatic juice, a deficit in enzyme activities still prevailed at the end of refeeding. The retention thresholds (total activity in pancreas $v$. activity per $h$ in pancreatic juice) of hydrolases were increased by malnutrition. They were all decreased by refeeding at various rates, but after 3 months of refeeding the thresholds were still markedly increased for all enzymes studied. After malnutrition and during refeeding, the dissociated enzyme activities in pancreas and pancreatic juice could be the expression of an alteration at different stages: synthesis, intracellular transport, storage mechanisms and secretion.
\end{abstract}

Pancreatic secretion: Digestive enzymes: Protein malnutrition and rehabilitation: Rat

After protein malnutrition followed by nutritional rehabilitation, a deficit in pancreatic digestive enzyme efficiency can persist in children (Danus et al. 1970) and the rat (Klotz et al. 1972), despite apparent recovery. Previous reports (Kheroua \& Belleville, 1981) have shown that in growing rats depleted of protein for 1 month activities and levels of enzymes in the pancreas and pancreatic juice are depressed. However, the changes in the concentrations of the various enzymes appear to be non-parallel, and modified independently of each other (Prost et al. 1988, 1990). Reversibility of these changes with subsequent nutritional rehabilitation has been examined over a short time-period. Generally, balanced refeeding involves a rebound effect at the first stage ( 24 or $48 \mathrm{~h}$ ), but 
this effect is often followed by a further decrease (Prost et al. 1990) and total recovery seems to require more time. Moreover, in order to relate food composition with digestive capacity it is important to determine whether recovery occurs at the same time for all enzymes.

In children, severe malnutrition leads to a reduction in the secretion of pancreatic enzymes; the condition appears to be reversible after correction of dietary deficiency (Barbezat \& Hansen, 1968). Recovery of pancreatic enzyme concentrations to normal levels has also been shown in the course of refeeding of fasted adult rats (Lee et al. 1982). Reversal of changes in the developing pancreas after malnutrition and dietary rehabilitation, however, has not been studied previously except in the study of Rossi et al. (1983), when malnutrition was induced in the immediate postnatal period by extending the size of newborn litters; however, this study was carried out only on the pancreas and not on pancreatic juice. In the present study experimental protein malnutrition was induced in the immediate post-weaning period by feeding a $30 \mathrm{~g}$ cereal protein $/ \mathrm{kg}$ diet for 1 month. Since reversibility of the adverse effects of malnutrition on the pancreas has been studied only to a limited extent, the enzyme activities in the pancreas and pancreatic juice were studied in parallel and chronologically during nutritional rehabilitation ( $235 \mathrm{~g}$ mixed protein $/ \mathrm{kg}$ diet) for up to 3 months until the body weight deficit was regained. Several enzyme activities were determined at the end of the period of malnutrition and during the period of rehabilitation: amylase (EC 3.2.1.1), lipase (EC 3.1.1.3), trypsin (EC 3.4.21.4), chymotrypsin (EC 3.4.21.1), phospholipase A2 (EC 3.1.1.4) and cholesterolesterase (EC 3.1.1.13). Since each enzyme has a specific synthesis, transport and secretion process (Prost et al. 1988, 1990), it is interesting to investigate the particular sensitivity of each enzyme to both nutritional phases.

The purpose of the present study was: (1) to evaluate whether the enzymic pancreatic juice changes caused by immediate post-weaning malnutrition are reversible and at what rate for each enzyme, and (2) to compare the same enzyme activities in the pancreas and its secretion in order to evaluate the changes of retention thresholds in the acinar cells at the end of malnutrition and during nutritional rehabilitation.

\section{EXPERIMENTAL METHODS}

Animals and diets. At $21 \mathrm{~d}$ of age, 168 male Wistar rats (Iffa-Credo, Lyon, France) weighing 40 (SE 5) g at the beginning of the experiment, were randomized into two equal groups. A control group $(\mathrm{C})$ was fed on a balanced diet containing $235 \mathrm{~g}$ mixed protein from animal and vegetable origins $/ \mathrm{kg}$ for 4 months. An experimental group was fed on a diet containing $30 \mathrm{~g}$ cereal protein $/ \mathrm{kg}$ for 1 month (protein depleted; ED), then the balanced diet for 3 months (protein repleted; ER). In the low-protein diet the lower energy content, due to the lower protein content, was compensated by maize starch. Diets were purchased from IffaCredo (L'Arbresle, France). Both diets were isoenergetic $(15539 \mathrm{~kJ} / \mathrm{kg}$ diet) and given in powdered form. The composition of the diets is shown in Table 1. Animals were kept in wire-bottom cages at constant temperature $\left(25^{\circ}\right)$ and humidity $(65 \%)$ with a 07.00 19.00 hours light cycle. They had ad lib. access to food and water. Food intake and animal weights were measured daily. The general guidelines for the care and use of laboratory animals were followed (Council of European Communities, 1981).

Pancreas and pancreatic juice samples. At the end of the period of protein malnutrition and at 5,10,15,30,60,90 d of refeeding, twelve rats from both groups were used to obtain samples of pancreatic juice and pancreatic extract. After an overnight fast the first six rats from each group were fitted with a double pancreatic and biliary cannula to obtain pure pancreatic juice without bile (Colwell, 1951). In the immediate post-operative period the spontaneous flow-rate was very low and, sometimes, pancreatic juice was contaminated by active trypsin resulting from ductal cell lesions; hence, sampling was started $5 \mathrm{~h}$ after 
Table 1. Composition of diets

\begin{tabular}{|c|c|c|c|c|c|c|c|}
\hline \multirow[t]{2}{*}{ Diet... } & & \multicolumn{3}{|c|}{ Control } & \multicolumn{3}{|c|}{ Low-protein } \\
\hline & & $\mathrm{g} / \mathrm{kg}$ & $\%$ energy & $\mathrm{kJ} / \mathrm{kg}$ & $\mathrm{g} / \mathrm{kg}$ & $\%$ energy & $\mathrm{kJ} / \mathrm{kg}$ \\
\hline \multirow[t]{2}{*}{ Protein: } & Animal + vegetable* & 235 & 25 & 3929 & - & - & - \\
\hline & Vegetablet & - & $\ldots$ & - & 50 & $3 \cdot 2$ & 500 \\
\hline Lipid & Maize oil & 50 & 12 & 1880 & 50 & 12 & 1880 \\
\hline \multirow[t]{2}{*}{ Carbohydrate: } & Wheat starch & 545 & $58 \cdot 5$ & 9100 & 840 & $79 \cdot 4$ & 12373 \\
\hline & Sucrose & 40 & $4 \cdot 5$ & 680 & 50 & $5 \cdot 4$ & 836 \\
\hline Fibre & Cellulose & 50 & - & - & 50 & - & - \\
\hline Mineralst & & 40 & - & - & 40 & - & - \\
\hline Vitaminsई & & 20 & - & - & 20 & - & - \\
\hline
\end{tabular}

* Animal proteins originated from fish flour and blood powder, and vegetable proteins from wheat, barley, soya-bean flours and soya-bean cake.

+ Vegetable proteins originated from wheat, barley and maize fours.

\$ Minerals provided the following amounts $(\mathrm{g} / \mathrm{kg}$ diet): Ca 4, K 2.4, $\mathrm{Na} \mathrm{1 \cdot 6,} \mathrm{Mg} \mathrm{0 \cdot 4,} \mathrm{Fe} \mathrm{0.12,} \mathrm{Mn} \mathrm{0.032,}$ $\mathrm{Cu} 0.005, \mathrm{Zn} \mathrm{0.018,} \mathrm{Co} \mathrm{0.00004,} \mathrm{I} \mathrm{0.00002.}$

$\S$ Vitamins provided the following amounts $(\mathrm{mg} / \mathrm{kg}$ diet) : thiamine 40 , riboflavine 30 , nicotinic acid 140 , pyridoxine 20 , pyridoxal 300 , cyanocolabamin $0 \cdot 1$, ascorbic acid 1600 , DL- $\alpha$-tocopherol 340 , menadione 80 , calcium pantothenate 200 , choline 2720 , folic acid $10, p$-aminobenzoic acid 100 , biotin $0 \cdot 6$, retinol 12 , cholecalciferol $0 \cdot 125$.

cannulation. Pancreatic juice was collected in ice for $48 \mathrm{~h}$. During the sampling period rats were fasted but had ad lib. access to tap-water with added $\mathrm{NaCl}(120 \mathrm{~mm})$ and $\mathrm{CaCl}_{2}$ ( $27 \mathrm{~mm})$. No bile or pancreatic juice was re-introduced into the intestinal lumen. Under these experimental conditions the mean enzyme outputs obtained over a $48 \mathrm{~h}$ period have been shown to represent the protein secretion of unstimulated juice (Kheroua \& Belleville, 1981).

At the same time, the second six rats of each group were killed between 08.00 and 10.00 hours after an overnight fast. The pancreas was removed, trimmed free of fat, weighed, diluted with ice-cold water ( $1 \mathrm{ml} / 100 \mathrm{mg}$ tissue) and homogenized, using a Potter-Elvehjem homogenizer, to obtain pancreatic extracts. To avoid successive freezing and thawing, pancreatic juices and extracts were stored at $-25^{\circ}$ in the form of portions suitable for use for each test.

Chemical analysis and enzyme activity determination. Protein levels were determined according to the technique of Lowry et al. (1951) using bovine serum albumin as a standard. Pancreatic DNA and RNA contents were measured, after separation, by the method of Munro \& Fleck (1966). Except for amylase, all the enzyme activities were obtained by titrimetry, using a pH-stat Radiometer, with specific substrates. Chymotrypsin activity was determined by measuring the hydrolysis of the $N$-acetyl-L-tyrosine ethyl ester monohydrate, and that of trypsin by degradation of the $N$-benzoyl-L-arginine ethyl ester hydrochloride after activation of the pro-enzymes forms by exogenous trypsin, using the method of Figarella et al. (1965). Triacylglycerol lipase activity was tested according to the Borgström \& Hildebrand (1975) technique using a tributyrin substrate without bile salts. This technique allowed measurement of potential lipase activity independent of colipase present in pancreatic samples. Phospholipase A2 was measured according to De Haas et al. (1968), using egg-yolk extracts as substrate. Cholesterolesterase was determined as its capacity to esterify cholesterol with oleic acid (Prost et al. 1978). Amylase activity was determined by a spectrophotometric technique (Métais \& Bieth, 1968) using hydrolysis of starch. 
Enzyme activities in the pancreas were expressed as enzyme units per total pancreas and in pancreatic juice as enzyme units per $\mathrm{h}$. One enzyme unit corresponds to $1 \mu \mathrm{mol}$ substrate hydrolysed $/ \mathrm{min}$ at the appropriate $\mathrm{pH}$ and temperature.

The nutritional efficiency of the diets was determined using six rats of each group. Cumulative $\mathrm{N}$ balances were measured during 1-week periods at various stages during the periods of protein malnutrition and refeeding.

Statistical analysis. Results were expressed as arithmetic means with their standard errors. Statistical evaluation of the data was carried out after analysis of variance, by classification of the means using the Duncan's (1955) new multiple-range test. Differences were considered significant at $P<0.05$.

\section{RESULTS}

Body weight and food intake

At the end of the period of protein malnutrition, the weight of ED rats represented only $23.6 \%$ of that of C rats (ED 38 (SE 4) g, C 160 (SE 12) g; Table 2). During this period, energy intake $\left(\mathrm{kJ} / \mathrm{d}\right.$ per $\mathrm{kg}$ metabolic body weight $\left(\mathrm{W}^{0.75}\right)$ for group ED was $63 \%$ of that of controls.

During refeeding, ER rats presented an energy intake higher than that of $\mathrm{C}$ rats (on average $1451 v .1146 \mathrm{~kJ} / \mathrm{d}$ per $\mathrm{kg} \mathrm{W}^{0 \cdot 75}$ ). On refeeding, the body weight of ER rats increased rapidly and markedly, but 3 months of refeeding was necessary for the weights to be similar in both groups.

\section{$N$ intake and output and $N$ retention}

During the period of protein malnutrition, $\mathrm{N}$ intake and output and $\mathrm{N}$ retention were strongly diminished, but with duration of protein malnutrition the amount of $\mathrm{N}$ retained increased (Table 2). This latter finding was due to a decrease in urinary $\mathrm{N}$ loss. As soon as refeeding started, $\mathrm{N}$ intake and $\mathrm{N}$ retention increased whereas $\mathrm{N}$ outputs declined compared with those of $\mathrm{C}$ rats. During the period of protein malnutrition, a significant $(P<0.05)$ decrease in the apparent digestibility coefficient and a lower efficiency of $\mathrm{N}$ retention were observed in the ED group compared with the $\mathrm{C}$ group. These values were higher in the ER group compared with those of the $\mathrm{C}$ group throughout refeeding.

Gain of body, pancreas and relative pancreas weights during the period of observation During the period of refeeding the gains in body and pancreas weights were higher in ER rats than in $\mathrm{C}$ rats (on average +57 and $59 \%$ respectively; Table 3 ). The relative pancreas weight was reduced during and after the first month of refeeding in both groups. This value was enhanced by protein malnutrition and remained higher in ED rats than $C$ rats up to day 15 of refeeding.

\section{Protein, DNA and RNA content of pancreas}

In $\mathrm{C}$ rats the protein, DNA and RNA contents in total pancreas increased with age (Table 4). These values were markedly decreased during the period of protein malnutrition and remained lower in ER rats than those of $\mathrm{C}$ rats to the end of the experiment. Protein malnutrition diminished total pancreatic cell numbers (measured as mg DNA per pancreas) and total protein synthetic capacity (measured as mg RNA per pancreas and RNA:DNA).

RNA: DNA could be regarded as an index of translation. In $C$ rats this value fluctuated throughout the experiment. This value was low during the period of protein malnutrition and up to day 5 of refeeding, but from day 10 to day 15 the highest values were obtained in the ER group, and these values were similar for both ER and C rats from 1 month of refeeding to the end of the experiment. 


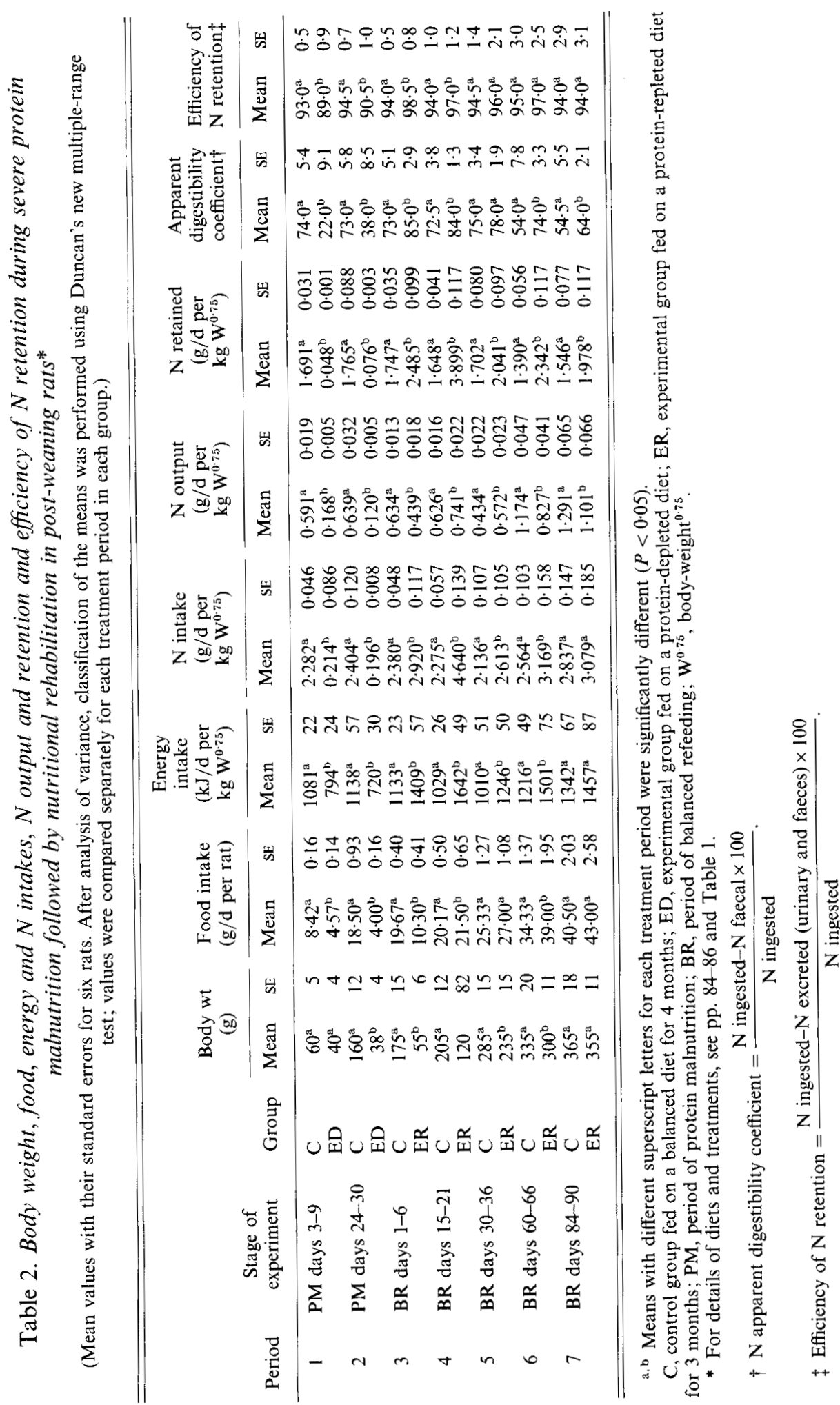


Table 3. Gain in body and pancreas weights during severe protein malnutrition followed by nutritional rehabilitation in post-weaning rats*

(Mean values with their standard errors for six rats. After analysis of variance, classification of the means was performed using Duncan's new multiple-range test; values were compared separately for each treatment period in each group.)

\begin{tabular}{|c|c|c|c|c|c|c|c|c|}
\hline \multirow{2}{*}{$\begin{array}{l}\text { Stage of } \\
\text { experiment }\end{array}$} & \multirow{2}{*}{$\begin{array}{l}\text { Age of rats } \\
\text { (d) }\end{array}$} & \multirow[b]{2}{*}{ Group } & \multicolumn{2}{|c|}{$\begin{array}{l}\text { Gain in body-wt } \\
\text { (g/rat per } d)\end{array}$} & \multicolumn{2}{|c|}{$\begin{array}{l}\text { Gain in pancreas wt } \\
(\mathrm{mg} / \text { rat per } \mathrm{d})\end{array}$} & \multicolumn{2}{|c|}{ Relative pancreas wt } \\
\hline & & & Mean & $\mathrm{SE}$ & Mean & SE & Mean & $\mathrm{SE}$ \\
\hline \multirow[t]{2}{*}{ PM $30 \mathrm{~d}$} & 52 & $\mathrm{C}$ & $400^{\mathrm{a}}$ & 0.05 & $7 \cdot 33^{b}$ & 0.09 & $204^{\mathrm{a}}$ & 21 \\
\hline & & ED & $-0.066^{b}$ & 0.00 & $-1 \cdot 33^{\mathrm{a}}$ & 0.03 & $263^{\mathrm{b}}$ & 28 \\
\hline \multirow[t]{2}{*}{ BR $5 \mathrm{~d}$} & 57 & $\mathrm{C}$ & $3 \cdot 00^{\mathrm{a}}$ & 0.25 & $13 \cdot 6^{\mathrm{a}}$ & $1 \cdot 4$ & $225^{\mathrm{a}}$ & 23 \\
\hline & & ER & $3 \cdot 40^{\mathrm{a}}$ & 0.40 & $22 \cdot 4^{b}$ & $2 \cdot 3$ & $385^{\mathrm{b}}$ & 40 \\
\hline \multirow[t]{2}{*}{ BR $10 \mathrm{~d}$} & 62 & $\mathrm{C}$ & $4 \cdot 00^{\mathrm{a}}$ & $0 \cdot 32$ & $13 \cdot 6^{\mathrm{a}}$ & 0.9 & $237^{\mathrm{a}}$ & 19 \\
\hline & & ER & $5 \cdot 40^{\mathrm{b}}$ & 0.51 & $9 \cdot 2^{\mathrm{h}}$ & $0 \cdot 7$ & $314^{\mathrm{b}}$ & 32 \\
\hline \multirow[t]{2}{*}{$\mathrm{BR} 15 \mathrm{~d}$} & 67 & $\mathrm{C}$ & $2 \cdot 00^{a}$ & $0 \cdot 15$ & $3 \cdot 0^{\mathrm{a}}$ & $0 \cdot 1$ & $223^{\mathrm{a}}$ & 15 \\
\hline & & ER & $7.60^{b}$ & 0.81 & $33 \cdot 2^{\mathrm{b}}$ & 1.5 & $353^{\mathrm{b}}$ & 33 \\
\hline \multirow[t]{2}{*}{ BR 1 month } & 82 & $\mathrm{C}$ & $4 \cdot 17^{\mathrm{a}}$ & 0.41 & $1.67^{a}$ & 0.09 & $169^{\mathrm{a}}$ & 15 \\
\hline & & ER & $7.67^{\mathrm{b}}$ & 0.38 & $-0.53^{b}$ & 0.02 & $177^{\mathrm{a}}$ & 10 \\
\hline \multirow[t]{2}{*}{ BR 2 months } & 112 & $\mathrm{C}$ & $1 \cdot 67^{\mathrm{a}}$ & 0.08 & $1 \cdot 47^{\mathrm{a}}$ & 0.08 & $157^{\mathrm{a}}$ & 12 \\
\hline & & ER & $2 \cdot 17^{\mathrm{b}}$ & $0 \cdot 16$ & $1 \cdot 43^{\mathrm{a}}$ & 0.07 & $153^{\mathrm{a}}$ & 8 \\
\hline \multirow[t]{2}{*}{ BR 3 months } & 142 & $\mathrm{C}$ & $1 \cdot 00^{\mathrm{a}}$ & 0.05 & $2 \cdot 30^{\mathrm{a}}$ & 0.15 & $163^{\mathrm{a}}$ & 9 \\
\hline & & ER & $1.83^{\mathrm{b}}$ & 0.06 & $4 \cdot 00^{\mathrm{b}}$ & $0 \cdot 12$ & $163^{\mathrm{a}}$ & 7 \\
\hline
\end{tabular}

a, b Means with different superscript letters for each treatment period were significantly different $(P<0.05)$.

$C$, control group fed on the balanced diet for 4 months; ED, experimental group fed on a protein-depleted diet for 1 month; ER, experimental group fed on the balanced diet for 3 months.

* For details of diets and treatments, see pp. 84-86 and Table 1.

Outputs of bile and pancreatic juice and content and output of protein in pancreatic juice Outputs of bile and pancreatic juice increased with age in $\mathrm{C}$ rats $(2 \cdot 8$-fold) between the end of the first month and the fourth month of the experiment whereas they were reduced by 3.4- and 1.7-fold respectively in ED rats (Table 5). During refeeding these outputs returned to control values by 1 month for bile and at day 15 for outputs of pancreatic juice.

The protein content of pancreatic juice fell $3 \cdot 75$-fold during the period of protein malnutrition and this decrease prevailed up to the first month of refeeding, then values for ER rats showed the greatest increase.

Outputs of protein in pancreatic juice increased with age in $\mathrm{C}$ rats (3.55-fold) between the end of the first month and the end of the experiment. They were reduced 6.54-fold in ED rats as the result of protein malnutrition. During refeeding, in ER rats, outputs were regularly increased for both groups up to 1 month of refeeding and from the second month the higher values were obtained in ER rats.

\section{Total enzyme activities in the pancreas and pancreatic juice}

In the pancreas (Table 6) all values were markedly reduced during the period of protein malnutrition, in decreasing order: amylase $(-88 \%)$, chymotrypsin $(-87 \%)$, trypsin $(-83 \%)$, lipase $(-77 \%)$, cholesterolesterase $(-72 \%)$, phospholipase A2 $(-71 \%)$. At day 10 of refeeding all values returned to control values, except lipase (day 15).

For pancreatic juice (Table 7), protein malnutrition reduced all enzyme outputs: chymotrypsin $(-94 \%)$, lipase and amylase $(-90.4 \%,-89 \%)$, phospholipase A2 $(-78 \%)$, cholesterolesterase $(-75 \%)$, trypsin $(-81.4 \%)$. During the period of refeeding, 
Table 4. Protein, DNA and RNA contents and RNA:DNA ratios in the pancreas of postweaning rats during severe protein malnutrition followed by nutritional rehabilitation*

(Mean values with their standard errors for six rats. After analysis of variance, classification of the means was performed using Duncan's new multiple-range test; values were compared separately for each treatment period in each group.)

\begin{tabular}{|c|c|c|c|c|c|c|c|c|c|c|c|c|}
\hline \multirow{2}{*}{$\begin{array}{l}\text { Stage of } \\
\text { experiment }\end{array}$} & \multirow{2}{*}{$\begin{array}{c}\text { Age of } \\
\text { rats } \\
\text { (d) }\end{array}$} & \multirow[b]{2}{*}{ Group } & \multicolumn{2}{|c|}{$\begin{array}{l}\text { Pancreas wt } \\
\text { (mg) }\end{array}$} & \multicolumn{2}{|c|}{$\begin{array}{c}\text { Protein } \\
\text { (mg/pancreas) }\end{array}$} & \multicolumn{2}{|c|}{$\begin{array}{c}\text { DNA } \\
\text { (mg/pancreas) }\end{array}$} & \multicolumn{2}{|c|}{$\begin{array}{c}\text { RNA } \\
\text { (mg/pancreas) }\end{array}$} & \multicolumn{2}{|c|}{ RNA: DNA } \\
\hline & & & Mean & $\mathrm{SE}$ & Mean & $\mathrm{SE}$ & Mean & $\mathrm{SE}$ & Mean & $\mathrm{SE}$ & Mean & $\mathrm{SE}$ \\
\hline \multirow[t]{2}{*}{ PM $30 \mathrm{~d}$} & \multirow[t]{2}{*}{52} & $\mathrm{C}$ & $326^{\mathrm{a}}$ & 12 & $23 \cdot 15^{\mathrm{a}}$ & 0.65 & $1.33^{a}$ & 0.26 & $4 \cdot 24^{a}$ & 0.49 & $3 \cdot 20^{a}$ & 0.20 \\
\hline & & ED & $100^{\mathrm{b}}$ & 15 & $7 \cdot 90^{\mathrm{b}}$ & $0 \cdot 30$ & $0.79^{b}$ & $0 \cdot 10$ & $2 \cdot 00^{\mathrm{b}}$ & $0 \cdot 20$ & $2 \cdot 50^{\mathrm{b}}$ & $0 \cdot 16$ \\
\hline \multirow[t]{2}{*}{ BR $5 \mathrm{~d}$} & \multirow[t]{2}{*}{57} & $\mathrm{C}$ & $394^{\mathrm{a}}$ & 42 & $43.73^{\mathrm{a}}$ & 1.97 & $1 \cdot 81^{\mathrm{a}}$ & 0.28 & $5 \cdot 52^{\mathrm{a}}$ & 0.75 & $3 \cdot 00^{\mathrm{a}}$ & 0.14 \\
\hline & & ER & $212^{b}$ & 25 & $21 \cdot 12^{\mathrm{b}}$ & 0.84 & $1 \cdot 12^{\mathrm{b}}$ & 0.19 & $2 \cdot 86^{\mathrm{b}}$ & 0.44 & $2 \cdot 50^{\mathrm{b}}$ & 0.11 \\
\hline \multirow[t]{2}{*}{ BR $10 \mathrm{~d}$} & \multirow[t]{2}{*}{62} & $\mathrm{C}$ & $462^{\mathrm{a}}$ & 24 & $54.52^{\mathrm{a}}$ & $3 \cdot 59$ & $1.99^{\mathrm{a}}$ & 0.23 & $7 \cdot 76^{a}$ & 0.55 & $3 \cdot 90^{\mathrm{a}}$ & 0.21 \\
\hline & & ER & $258^{\mathrm{b}}$ & 30 & $49 \cdot 54^{\mathrm{a}}$ & $3 \cdot 71$ & $1 \cdot 29^{b}$ & $0 \cdot 19$ & $6 \cdot 37^{a}$ & $0 \cdot 80$ & $4 \cdot 90^{\mathrm{b}}$ & 0.30 \\
\hline \multirow[t]{2}{*}{ BR $15 \mathrm{~d}$} & \multirow[t]{2}{*}{67} & $\mathrm{C}$ & $457^{a}$ & 16 & $72 \cdot 66^{\mathrm{a}}$ & 6.40 & $3 \cdot 56^{\mathrm{a}}$ & 0.41 & $6 \cdot 76^{\mathrm{a}}$ & 0.46 & $1.90^{\mathrm{a}}$ & $0 \cdot 35$ \\
\hline & & ER & $424^{\mathrm{a}}$ & 15 & $54 \cdot 27^{\mathrm{b}}$ & $6 \cdot 36$ & $1.74^{b}$ & $0 \cdot 13$ & $4 \cdot 88^{\mathrm{b}}$ & 0.59 & $2 \cdot 80^{\mathrm{b}}$ & 0.41 \\
\hline \multirow{2}{*}{ BR 1 month } & \multirow[t]{2}{*}{82} & $\mathrm{C}$ & $482^{\mathrm{a}}$ & 38 & $81 \cdot 94^{\mathrm{a}}$ & $7 \cdot 71$ & $4 \cdot 34^{\mathrm{a}}$ & 0.29 & $10 \cdot 60^{\mathrm{a}}$ & 0.91 & $2 \cdot 44^{a}$ & $0 \cdot 31$ \\
\hline & & ER & $416^{b}$ & 19 & $63 \cdot 23^{\mathrm{b}}$ & $7 \cdot 49$ & $3 \cdot 16^{\mathrm{b}}$ & $0 \cdot 16$ & $7 \cdot 49^{b}$ & 0.50 & $2 \cdot 37^{\mathrm{a}}$ & $0 \cdot 33$ \\
\hline \multirow[t]{2}{*}{ BR 2 months } & \multirow[t]{2}{*}{112} & $\mathrm{C}$ & $526^{\mathrm{a}}$ & 32 & $126 \cdot 77^{\mathrm{a}}$ & $14 \cdot 20$ & $5 \cdot 21^{\mathrm{a}}$ & $0 \cdot 47$ & $12 \cdot 62^{\mathrm{a}}$ & 0.89 & $2 \cdot 42^{\mathrm{a}}$ & $0 \cdot 41$ \\
\hline & & ER & $459^{\mathrm{b}}$ & 22 & $80 \cdot 78^{\mathrm{b}}$ & 10.56 & $3.95^{\mathrm{b}}$ & $0 \cdot 45$ & $9 \cdot 41^{\mathrm{b}}$ & 0.44 & $2 \cdot 38^{\mathrm{a}}$ & $0 \cdot 28$ \\
\hline \multirow[t]{2}{*}{ BR 3 months } & \multirow[t]{2}{*}{142} & $\mathrm{C}$ & $595^{\mathrm{a}}$ & 38 & $149 \cdot 94^{\mathrm{a}}$ & $14 \cdot 28$ & $8.99^{\mathrm{a}}$ & 1.25 & $16 \cdot 69^{a}$ & $1 \cdot 19$ & $1.85^{\mathrm{a}}$ & 0.28 \\
\hline & & ER & $579^{\mathrm{a}}$ & 31 & $125 \cdot 64^{\mathrm{a}}$ & $12 \cdot 74$ & $8 \cdot 80^{\mathrm{a}}$ & 0.98 & $13 \cdot 32^{\mathrm{b}}$ & 0.87 & $1 \cdot 51^{\mathrm{a}}$ & 0.25 \\
\hline
\end{tabular}

a.b Means with different superscript letters for each treatment period were significantly different $(P<0.05)$.

$C$, control group fed on the balanced diet for 4 months; ED, experimental group fed on a protein-depleted diet for 1 month; ER, experimental group fed on the balanced diet for 3 months.

* For details of diets and treatments, see pp. $84-86$ and Table 1.

trypsin and cholesterolesterase levels for ER rats reached control values after $10 \mathrm{~d}$ of refeeding, the corresponding period for lipase being $15 \mathrm{~d}$, phospholipase A2 1 month, amylase and chymotrypsinogen 2 months of refeeding.

\section{Enzyme retention thresholds for pancreas (enzyme units per pancreas) v. pancreatic juice (enzyme units/h)}

When the value for enzyme activity in pancreas: that in pancreatic juice decreased, it meant that the enzyme retention threshold was increased in pancreas, being inversely related to that for pancreatic juice (Table 8). In $C$ rats, retention threshold values varied between hydrolases and with the age of the rats.

Protein malnutrition increased retention thresholds of chymotrypsin, lipase and phospholipase A2. The retention threshold was strongly increased for amylase at day 5 of refeeding and for trypsin at day 10 of refeeding. It remained elevated for phospholipase A2 up to 1 month during refeeding, for trypsin up to 2 months and for amylase, chymotrypsin and lipase up to 3 months.

\section{DISCUSSION}

The experiment was performed on post-weaning rats, which were adults (4 months old) at the end of the experiment. As the control values changed with time, it was essential to compare C, ED and ER rats at the same time-intervals.

The protein-deficient diet used in the present experiment approximated to the diets with poor protein intake of low biological value eaten by children in some countries. The ED rats ate $73 \%$ of the energy intake per $\mathrm{kg} \mathrm{W}^{0.75}$ per day of $\mathrm{C}$ rats but consumed only 
Table 5. Bile and pancreatic juice outputs, protein contents and protein outputs of pancreatic juice of post-weaning rats during severe protein malnutrition followed by nutritional rehabilitation*

(Mean values with their standard errors for six rats. After analysis of variance, classification of the means was performed using Duncan's new multiple-range test; values were compared separately for each treatment period in each group.)

\begin{tabular}{|c|c|c|c|c|c|c|c|c|c|c|}
\hline \multirow{2}{*}{$\begin{array}{l}\text { Stage of } \\
\text { experiment }\end{array}$} & \multirow{2}{*}{$\begin{array}{c}\text { Age of } \\
\text { rats } \\
\text { (d) }\end{array}$} & \multirow[b]{2}{*}{ Group } & \multicolumn{2}{|c|}{$\begin{array}{l}\text { Bile output } \\
(\mathrm{ml} / \mathrm{h})\end{array}$} & \multicolumn{2}{|c|}{$\begin{array}{l}\text { Pancreatic juice } \\
\text { output }(\mathrm{ml} / \mathrm{h})\end{array}$} & \multicolumn{2}{|c|}{$\begin{array}{l}\text { Protein contents } \\
\qquad(\mathrm{mg} / \mathrm{ml})\end{array}$} & \multicolumn{2}{|c|}{$\begin{array}{l}\text { Protein output } \\
\qquad(\mathrm{mg} / \mathrm{h})\end{array}$} \\
\hline & & & Mean & SE & Mean & SE & Mean & $\mathrm{SE}$ & Mean & $\mathrm{SE}$ \\
\hline \multirow[t]{2}{*}{ PM $30 \mathrm{~d}$} & \multirow[t]{2}{*}{52} & $\mathrm{C}$ & $0 \cdot 17^{\mathrm{a}}$ & 0.05 & $0 \cdot 12^{\mathrm{a}}$ & 0.02 & $6 \cdot 00^{\mathrm{a}}$ & 0.72 & $0.72^{\mathfrak{u}}$ & $0 \cdot 15$ \\
\hline & & ED & $0.05^{\mathrm{b}}$ & 0.02 & $0.07^{\mathrm{b}}$ & 0.02 & $1 \cdot 60^{\mathrm{b}}$ & 0.28 & $0 \cdot 11^{\mathrm{D}}$ & 0.05 \\
\hline \multirow[t]{2}{*}{ BR $5 \mathrm{~d}$} & \multirow[t]{2}{*}{57} & $\mathrm{C}$ & $0.21^{a}$ & 0.06 & $0 \cdot 13^{\mathrm{a}}$ & $0 \cdot 03$ & $9 \cdot 35^{a}$ & $1 \cdot 20$ & $1 \cdot 22^{\mathrm{a}}$ & 0.34 \\
\hline & & ER & $0 \cdot 10^{\mathrm{b}}$ & 0.04 & $0 \cdot 10^{\mathrm{a}}$ & 0.02 & $2 \cdot 00^{\mathrm{b}}$ & 0.51 & $0 \cdot 20^{\mathrm{b}}$ & 0.04 \\
\hline \multirow[t]{2}{*}{ BR $10 \mathrm{~d}$} & \multirow[t]{2}{*}{62} & $\mathrm{C}$ & $0.31^{\mathrm{a}}$ & 0.04 & $0 \cdot 16^{\mathrm{a}}$ & 0.04 & $8 \cdot 70^{\mathrm{a}}$ & $1 \cdot 34$ & $1 \cdot 39^{\mathrm{a}}$ & $0 \cdot 38$ \\
\hline & & ER & $0 \cdot 20^{\mathrm{b}}$ & 0.03 & $0.13^{\mathrm{a}}$ & 0.03 & $3 \cdot 00^{\mathrm{b}}$ & 0.64 & $0 \cdot 39^{\mathrm{b}}$ & $0 \cdot 12$ \\
\hline \multirow[t]{2}{*}{ BR $15 \mathrm{~d}$} & \multirow[t]{2}{*}{67} & $\mathrm{C}$ & $0.33^{\mathrm{a}}$ & 0.07 & $0 \cdot 21^{\mathrm{a}}$ & 0.05 & $9 \cdot 00^{\mathrm{a}}$ & 1.56 & $1.89^{\mathrm{a}}$ & 0.40 \\
\hline & & ER & $0.25^{\mathrm{a}}$ & 0.05 & $0 \cdot 19^{\mathrm{a}}$ & 0.04 & $3 \cdot 40^{\mathrm{b}}$ & $1 \cdot 12$ & $0.65^{\mathrm{b}}$ & 0.15 \\
\hline \multirow[t]{2}{*}{ BR 1 month } & \multirow[t]{2}{*}{82} & $\mathrm{C}$ & $0.35^{2}$ & 0.08 & $0 \cdot 22^{\mathrm{a}}$ & 0.05 & $9 \cdot 60^{a}$ & $1 \cdot 41$ & $2 \cdot 11^{\mathrm{a}}$ & 0.41 \\
\hline & & ER & $0.33^{a}$ & $0 \cdot 06^{a}$ & $0.20^{a}$ & 0.04 & $5 \cdot 50^{\mathrm{b}}$ & $1 \cdot 20$ & $1 \cdot 10^{\mathrm{b}}$ & 0.29 \\
\hline \multirow{2}{*}{ BR 2 months } & \multirow[t]{2}{*}{112} & $\mathrm{C}$ & $0.42^{\mathrm{a}}$ & 0.08 & $0.28^{\mathrm{a}}$ & 0.07 & $8 \cdot 00^{\mathrm{a}}$ & $1 \cdot 10$ & $2 \cdot 24^{\mathrm{a}}$ & 0.22 \\
\hline & & ER & $0.44^{\mathrm{a}}$ & 0.09 & $0.27^{\mathrm{a}}$ & 0.08 & $11 \cdot 00^{\mathrm{b}}$ & 0.92 & $2 \cdot 97^{\mathrm{b}}$ & 0.30 \\
\hline \multirow[t]{2}{*}{ BR 3 months } & \multirow[t]{2}{*}{142} & $\mathrm{C}$ & $0 \cdot 47^{\mathrm{a}}$ & $0 \cdot 10$ & $0 \cdot 33^{a}$ & 0.06 & $7 \cdot 75^{\mathrm{a}}$ & 0.88 & $2 \cdot 56^{\mathrm{a}}$ & 0.25 \\
\hline & & ER & $0.52^{\mathrm{a}}$ & 0.12 & $0 \cdot 32^{\mathrm{a}}$ & 0.07 & $11.00^{\mathrm{b}}$ & 1.20 & $3.52^{\mathrm{b}}$ & $0 \cdot 31$ \\
\hline
\end{tabular}

${ }^{a, b}$ Means with different superscript letters for each treatment period were significantly different $(P<0 \cdot 05)$.

$C$, control group fed on the balanced diet for 4 months; ED, experimental group fed on a protein-depleted diet for 1 month; ER, experimental group fed on the balanced diet for 3 months.

* For details of diets and treatments, see pp. 8486 and Table 1.

$8 \cdot 2-9 \cdot 3 \%$ of their $\mathrm{N}$ intake (per $\mathrm{kg} \mathrm{W}^{0.75}$ per day). The effect of a deficient $\mathrm{N}$ supply was rapid, since a fall in $\mathrm{N}$ retention was evident from the first days of protein malnutrition. The efficiency of $N$ retention was moderately decreased by protein malnutrition and then values became higher than those obtained with older rats (Kheroua \& Belleville, 1981) consuming the same low-protein diet. These results gave evidence of a higher digestibility and retention of cereal-protein- $\mathrm{N}$ in young rats. These values improved with the duration of protein malnutrition. Adaptation to protein malnutrition was also observed in children (Shakir et al. 1972). During the same period, values for $\mathrm{N}$ output were reduced. This improved utilization of alimentary $\mathrm{N}$ persisted up to the third month of refeeding and involved the return of body weight to control values. The increased relative pancreas weights during malnutrition proved that this tissue was less impaired by malnutrition than the whole organism.

Protein malnutrition strongly decreased the protein, DNA and RNA contents of the pancreas $(-66,-40.6$ and $-52.8 \%$ respectively). Since protein contents were found to change more than DNA and RNA contents, it could be suggested that translation and transcription were inhibited by protein malnutrition. This nutritional depletion involved a reduction in total pancreatic cell number as indicated by total DNA, and a proportionally higher diminution in total protein synthetic capacity as indicated by total RNA and total RNA : total DNA. Protein and DNA contents per pancreas did not return to control values until 3 months and there was a deficit in RNA content up to the end of the experiment. At the beginning of rehabilitation, protein synthesis increased more in the refed rats than in the controls. 
NUTRITIONAL REHABILITATION AND EXOCRINE PANCREAS

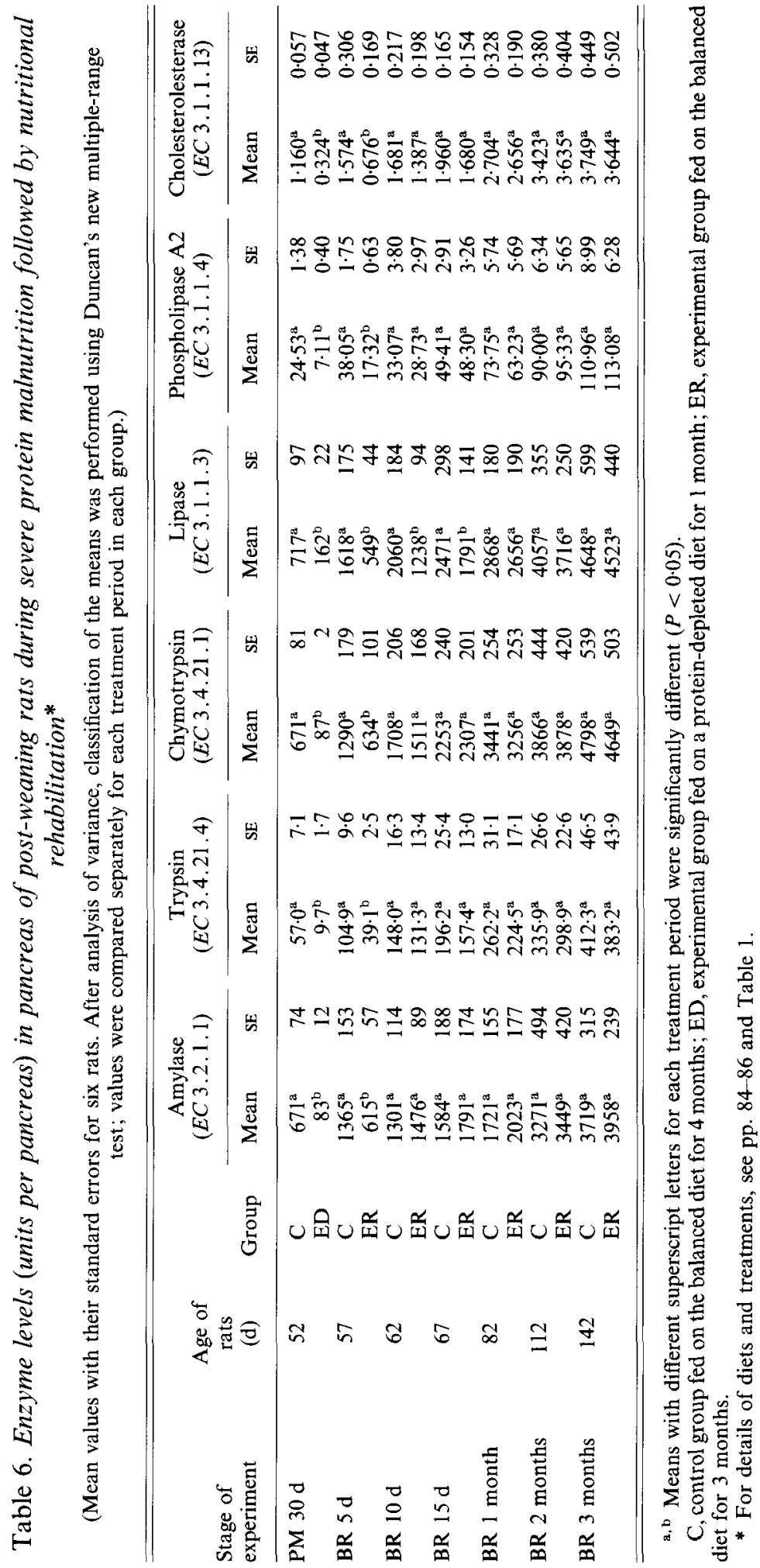


K. MOHAMED-BENKADA AND OTHERS

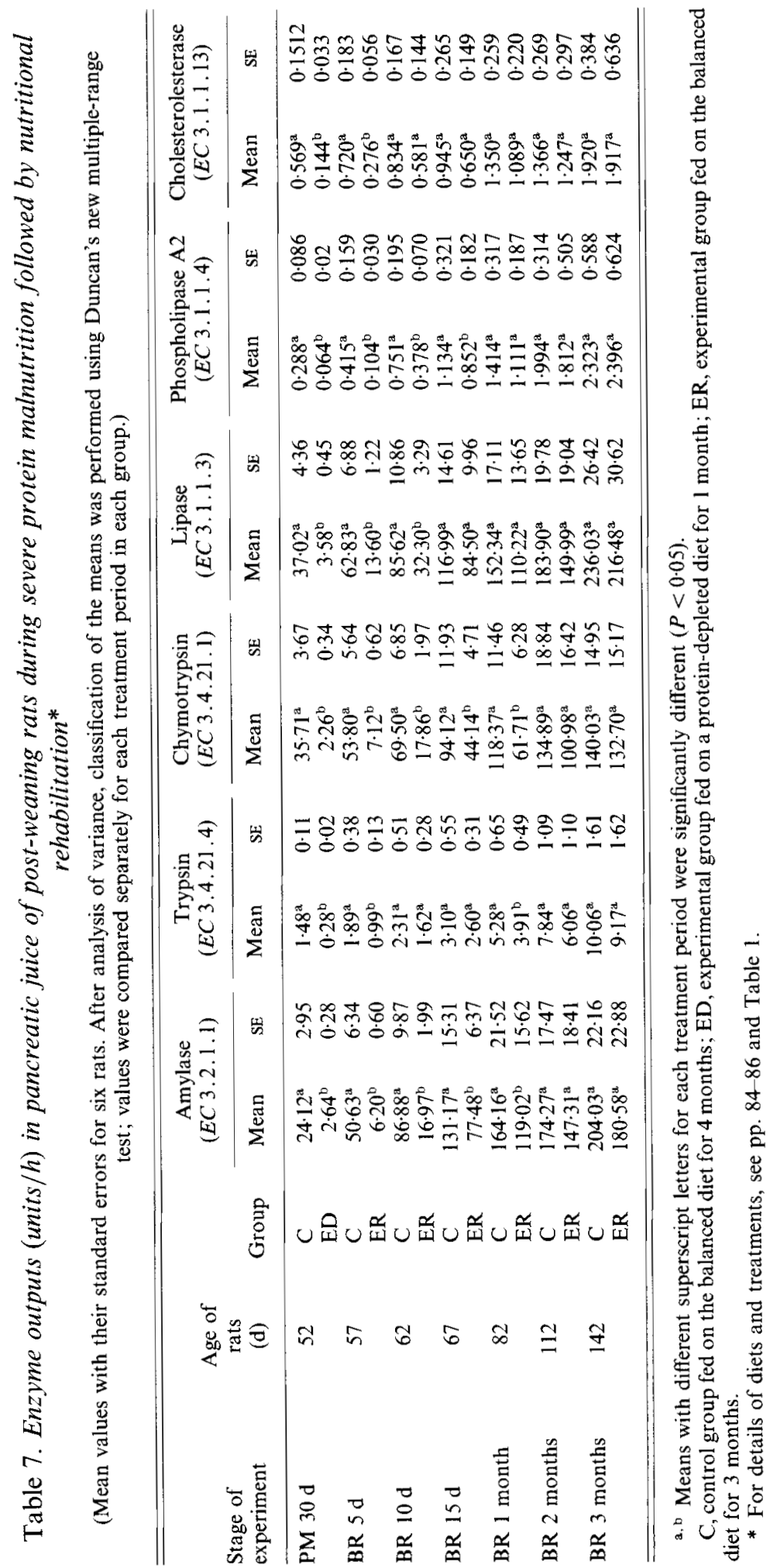




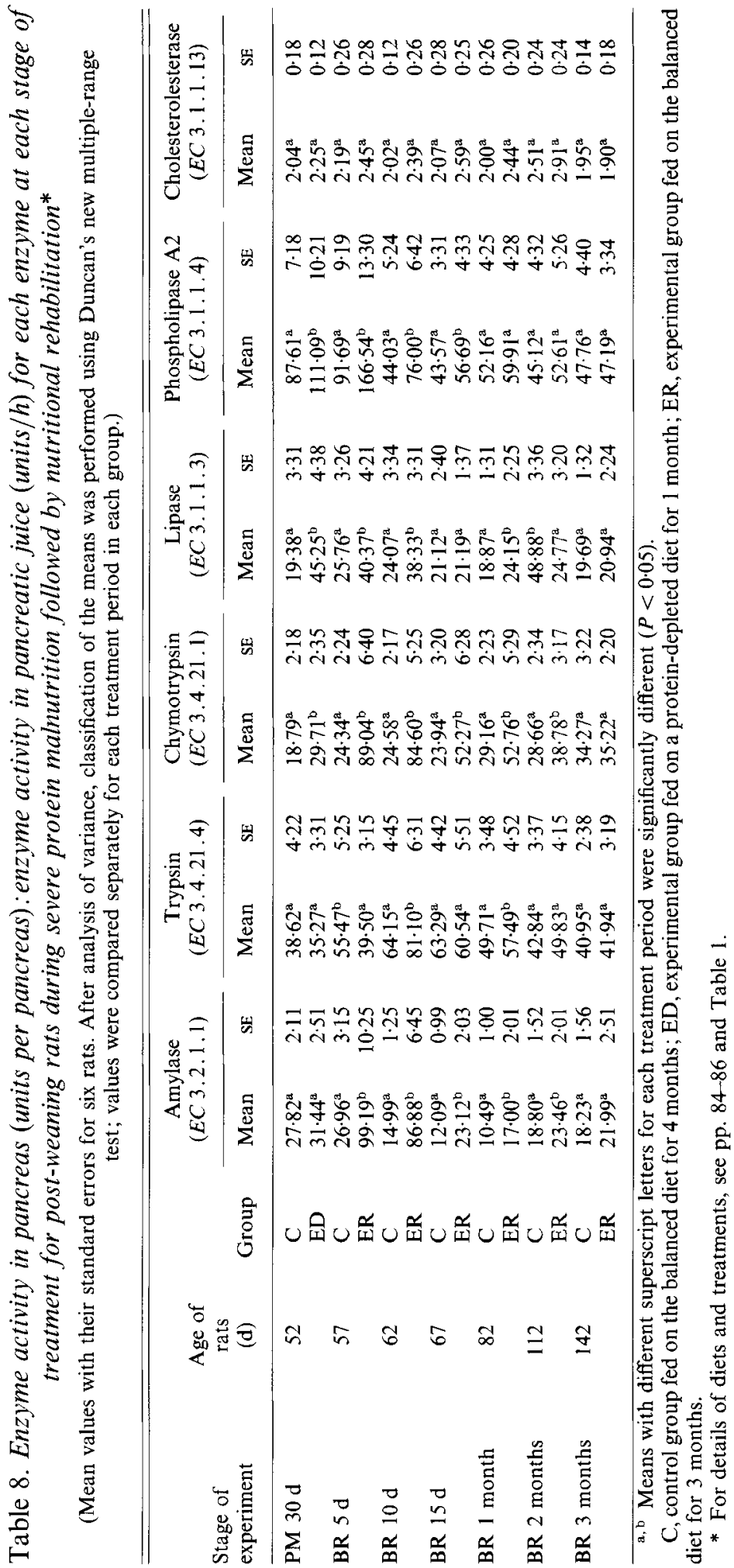


Protein malnutrition was associated with a greater reduction in secretion of bile than of pancreatic juice. Studies conducted on children affected by kwashiorkor or marasmus showed that the output of pancreatic juice is modified little (Barbezat \& Hansen, 1968; Danus et al. 1970). However, the main consequence of protein malnutrition is the fall in the protein content of pancreatic juice, which involved a very low protein output. This decrease has been verified consistently even in older animals (Kheroua \& Belleville, 1981), in which it is lower than that of the present study. The decrease in the amounts of bile, pancreatic juice and protein secreted could be attributable to disturbances in liver and pancreas metabolism and also to impairment of the duodenal mucosa. These changes may decrease basal duodenal hormone (cholecystokinin (CCK) and secretin) secretion. Moreover, in isolated pancreatic islets CCK efficiency is reduced or suppressed by malnutrition (Prost \& Belleville, 1991). Refeeding rapidly restored pancreatic juice output (day 5), more slowly that of bile (day 15), while the protein content and output of pancreatic juice remained significantly depressed up to 1 month of rehabilitation. In contrast, from the second to the third months of refeeding these values were higher for ER rats compared with $\mathrm{C}$ rats. Hence, it can be stated that the effects of protein malnutrition disappeared very slowly.

Protein malnutrition was associated with a greater impairment in the output of pancreatic juice enzymes than in content of enzymes in the pancreas for chymotrypsinogen, lipase and phospholipase A2; therefore, the retention thresholds of these enzymes were enhanced. On the other hand, similar changes were found in the pancreas and pancreatic juice for amylase trypsin and cholesterolesterase activities; therefore, in both groups the retention thresholds of these enzymes were similar. At day 5 of refeeding, retention thresholds of amylase, and chymotrypsin activities were significantly higher than control values, with more modest increases for lipase, phospholipase A2 and cholesterolesterase activities, because the rate of enzyme synthesis increased more than that of output. Only the trypsin retention threshold was still decreased at the beginning of refeeding. For ER rats retention thresholds were similar to those for $\mathrm{C}$ rats at day 5 for cholesterolesterase, at 1 month for phospholipase A2, at 2 months for trypsin and at 3 months for amylase, chymotrypsin and lipase. In the long term, the beneficial effects of refeeding were less obvious for pancreatic juice than for the pancreas. These findings provided evidence of non-parallelism supported by changes in the proportion of each hydrolase in pancreas and pancreatic juice.

The age at which malnutrition occurs may influence the changes that occur. Results obtained with the same protein-depleted diet but using adult rats (Kheroua \& Belleville, 1981) indicated that amylase and phospholipase A2 activities are reduced more while those of lipase, chymotrypsin and trypsin are decreased less than in the present study.

The lack of parallelism between enzyme activities in the pancreas and its secretion during malnutrition and refeeding, and with age in both treatment groups, raises a basic problem in exocrine pancreas physiology. Indeed, according to the theories of Babkin (1950) and Palade (1975), the proportions of the various enzymes in pancreatic secretion should only be affected by their relative rates of synthesis. Our results invalidate this hypothesis.

Our results support those of Dagorn \& Mitchel (1976), who suggest that zymogen granules would be formed by several pools of variable composition and according to the stimulating factors the secretion of a particular pool could be favoured. Dagorn et al. (1977) showed that the lack of parallelism between two enzyme activities might be due to various changes in synthesis, as well as in transport and excretion. Rothman (1977) suggested that each enzyme could be secreted independently and that its intracellular transport could also be non-parallel.

Non-parallelism might be explained in other ways: Malaisse-Lagae et al. (1975) showed that the acinar cell population has heterogeneous relative enzyme contents related to the 
pancreatic site; the amylase:chymotrypsin value was higher in cells distant from the islets of Langerhans than in those closer. Moreover, Bruzzone et al. (1986) showed that according to the level of stimulation, a particular cell population might be more affected than another and differences are observed in pancreatic enzymes released from ventral and dorsal areas of the rat pancreas.

In conclusion, our results clearly indicate that each pancreatic digestive enzyme possesses its own sensitivity to malnutrition and to refeeding, and that generally no correlation is observed between its activity in pancreas and that in pancreatic juice relative to age or nutritional changes. These differences are probably attributable to the fact that each enzyme exhibits its own synthesis, transport and secretion rates, that evolve with age and nutritional conditions in a non-parallel way.

This work was supported by 86 MES 25 research grants from the French Foreign Office. We convey our thanks to Anne Magnet, a linguist at the University of Burgundy, for editing the manuscript in English.

\section{REFERENCES}

Babkin, B. P. (1950), Enzymes of the pancreatic juice. In Secretory Mechanisms of Digestive Glands, 2nd ed., pp. 54-58 [Paul E. Hoeber, editor]. New York: Academic Press.

Barbezat, G. D. \& Hansen, J. D. L. (1968). The exocrine pancreas and protein caloric malnutrition. Pediatrics 42 , $77-92$.

Borgström, B. \& Hildebrand, H. (1975). Lipase and colipase activities of human small intestinal contents after a liquid test meal. Scandinavian Journal of Gastroenterology 10, 585-591.

Bruzzone, R., Trimble, E. R., Gjinovci, A. \& Renold, E. R. (1986). Differences in pancreatic enzyme release from ventral and dorsal areas of the rat pancreas. American Journal of Physiology 251, G56-G63.

Colwell, A. R. (1951). Collection of pancreatic juice from rats and consequences of its continued loss. American Journal of Physiology 164, 812-821.

Council of European Communities (1986). Official Journal of the European Communities Legislation L. 358, 1-28.

Dagorn, J. C. \& Mitchel, R. (1976). Non-parallel courses of intra pancreatic levels of exportable enzymes after a fatty meal. Proceedings of the Society for Experimental Biology and Medicine 151, 608-610.

Dagorn, J. C., Paradis, D. \& Morisset, J. (1977). Non-parallel response of amylase and chymotrypsinogen biosynthesis following pancreatic stimulation: a possible explanation for observed non-parallelism in pancreatic secretion. Digestion $15,110-120$.

Danus, O., Urbina, A. M., Valenzuela, I. \& Solimano, G. (1970). The effect of refeeding on pancreatic exocrine function in marasmic infant. Tropical Pediatrics 77, 334-337.

De Haas, G. H., Postema, N. M., Nieuwenhuizen, W. \& Van Deenen, L. L. M. (1968). Purification and properties of phospholipase A from porcine pancreas. Biochimica et Biophysica Acta 159, 103-117.

Duncan, D. B. (1955). Multiple range and multiple F tests. Biometrics 11, 1-40.

Figarella, C., Taulier, J. \& Sarles, H. (1965). Dosage de la chymotrypsine et de la trypsine dans le suc duodénal. (Determination of chymotrypsin and trypsin content in duodenal juice.) Bulletin de la société de Chimie Biologique 47, 679-686.

Kheroua, O. \& Belleville, J. (1981). Behaviour of digestive enzymes in the pancreatic juice and pancreas of rats fed on a low protein diet ( $3 \%$ of cereal protein) then on a balanced diet ( $23.5 \%$ of mixed protein). Reproduction, Nutrition et Développement 21, 901-917.

Klotz, A. P., Murdock, A. L. \& Svoboda, D. J. (1972). The effect of protein deprivation on pancreatic function in young animals and on animals in utero. Digestive Diseases 17, 399-406.

Lee, P. C., Brooks, S. \& Lebenthal, E. (1982). Effect of fasting and refeeding on pancreatic enzymes and secretagogues responsiveness in rat. American Journal of Physiology 242, G215-G222.

Lowry, O. H., Rosebrough, N. J., Farr, A. L. \& Randall, R. J. (1951). Protein measurement with the Folin phenol reagent. Journal of Biological Chemistry 193, 265-275.

Malaisse-Lagae, F., Ravazzola, M., Robberecht, P., Vandermeers, A., Malaisse, W. J. \& Orci, L. (1975). Exocrine pancreas: evidence for topographic partition of secretory function. Science 190, 795-797.

Metais, P. \& Bieth, J. (1968). Détermination de l'amylase par une microtechnique. (Determination of amylase by a microtechnique.) Annales de Biologie Clinique 26, 133-142.

Munro, H. N. \& Fleck, A. (1966). Recent developments in the measurement of nucleic acids in biological materials. Analyst 29, 280-287.

Palade, G. E. (1975). Intracellular aspects of the process of protein synthesis. Science 189, 347-358.

Prost, J. \& Belleville, J. (1991). Age and protein restriction followed by balanced refeeding effect on pancreatic digestive enzyme outputs and turnover times in rats. Journal of Nutrition 121, 2044-2054. 
Prost, J., Belleville, J. \& Gillet, M. (1978). Effets de régimes hyperlipidiques et isoprotéiques sur les activités de la lipase, de la phospholipase A2, de la cholestérolestérase de la trypsine et de l'amylase du suc pancréatique et du pancréas de rat. (Effect of isoproteinic and lipid-rich diets on lipase, phospholipase $A_{2}$, cholesterolesterase, trypsin and amylase activities in rat pancreatic juice and pancreas.) Journal de Physiologie 74, 743-754.

Prost, J., Belleville, J.\& Valantin-Rollet, C. (1988). Effects of age and protein malnutrition followed by a balanced diet on the non-parallel change in digestive enzymes in the pancreas and their secretion in the rat. British Journal of Nutrition 60, 619-631.

Prost, J., Belleville, J. \& Valantin-Rollet, C. (1990). Time course of changes in rat pancreatic synthesis rates and retention thresholds of four hydrolases during consumption of a low-protein followed by a balanced diet. Nutrition 6, 247-253.

Rossi, T. M., Lee, P. C. \& Lebenthal, E. (1983). Effect of feeding regimens on the functional recovery of pancreatic enzymes in postnatally malnourished weaning rats. Pediatrics Research 17, 806-809.

Rothman, S. S. (1977). The digestive enzymes of the pancreas: a mixture of inconstant proportions. Annual Review of Physiology 39, 373-389.

Shakir, A., Dematchi, M. \& El Milli, N. (1972). Pattern of protein caloric malnutrition in young children attending an out patient clinic in Baghdad. Lancet ii, 143-146. 